\title{
The Path of Transition: From the Past towards Efficient Armed Forces
}

\begin{abstract}
Michael H. Clemmesen ${ }^{1}$
Lithuania, Latvia, and Estonia have now succeeded in achieving the main goal of their security policy aspirations: all three were invited to join NATO at the November Prague Summit. The mature political and economic development in the three- very different—-states has made this step natural. During the last five or so years the three have also gradually accelerated their efforts to prepare their developing armed forces for a role in the Alliance. This task has not been and will not be easy. One of the reasons is that this task included first a build-up from scratch and thereafter a total reform of those first structures. The latter challenge is similar to that required everywhere in the Central and Eastern European armed forces: to make them focused and cost-effective.

This article will cover different key aspects of the security reform needs in all these states, thereby indirectly covering the security situation in the Baltic States since 1991 and into the coming years. It is built on eight years of observation, study, conversations, and work in the three states as an insider, albeit one with the perspective of an outsider. In the last three years, the regional perspective has been supplemented and enriched with observations and conversations in several other Central and East European countries.
\end{abstract}

\section{The initial build-up of the Baltic states' armed forces}

In the period immediately following independence, the build-up of the armed forces was seen as urgent. During the first few years, there was an acute perception of threat. The Russian occupation troops were still present, and statements from a variety of sources in the Russian Federation reinforced the inherently problematic nature of their presence. Something had to be done, quickly, to develop the ability to fight back. This was not easy. Cadres for the armed forces had to be recruited. Some were found among the limited number of relatively untainted professionals from the Soviet Armed Forces. Others came from the volunteer cadres of the home guard forces that were created or recreated in 1990-91. The latter group was supplemented with officers, normally retired, from the Baltic diaspora in the U.S. and elsewhere. A strained relationship between these two groups and their political friends added to the problems on several occasions. None had any experience in building and operating armed forces in small democracies.

\footnotetext{
${ }^{1}$ Brigadier General Michael H. Clemmesen is Commandant, Baltic Defense College, Tartu, Estonia.
} 


\section{THE QUARTERLY JOURNAL}

The forces had to be armed and equipped. The withdrawing Russian forces took everything with them, and initially no states dared to donate and few were willing to sell armaments to the Baltic states, concerned as all were with the possible response of Russia. The military infrastructure was deliberately destroyed by the departing Russians, and was thereafter scavenged by the local population. Both what was destroyed and what was left was of very low quality. What had initially been well constructed in the Russian Empire or during the independence period had been undermined by bad maintenance, and what had been built in the last Soviet decades was in even worse shape.

Parallel to the build-up of the armed forces, the national economy had to be reformed and revitalized, and the state had to justify taxing the population for common projects by developing a new "social contract" and enhancing the legitimacy of the political system and trust in its leadership. This is still an unfinished process, and it was and remains far from obvious that a significant part of the limited available state resources should go to the development of the armed forces. Both a majority of the population and most politicians considered it futile to attempt to create independent self-defense forces. The maximum that most considered possible and desirable was the marking of the national will to exist by a fight at the border followed by guerrilla actions in the forests. Only a potential NATO framework for the armed forces could justify giving a high priority to their development beyond that basic level.

\section{Reform requirements throughout Central and Eastern Europe}

It is important to understand, and accept, that the transition outlined in the rest of the article is necessary for the creation of "best practice" Western-type armed forces for the variety of missions likely to arise in the post-Cold War era. The process is likely to be protracted before it is completed, likely spanning decades in most cases. It is relevant not only for the CEE states that aspire to and prepare for NATO membership, but also for new NATO member states that want to develop effective contributions to the alliance and to international operations in other frameworks. It is, however, also relevant for the states with a Soviet or Yugoslav heritage that only want to create effective, future-oriented armed forces. The reforms described are relevant no matter what main tasks the forces are given, their degree of specialization, and the level of resources made available for the creation and maintenance of the structures.

The Baltic States and nearly all other CEE states are at some point on the path towards the outlined situation. However, the CEE countries have much work to do before they reach a "best practice" level. They are not alone. Several West European states have apparently found it difficult to adjust their militaries and the political-military co-operation pattern away from that of Cold War optimization, which aimed at meeting the one and only threat. The required reforms go far beyond the creation of basic interoperability to ensure a reasonable level of 
English language understanding in the cadre, effective technical communications interfaces, as well as common communication, reporting, and command formats. They even go beyond creating the "human interoperability" that comes from the ability to accept and understand different national and organizational cultures well enough to co-operate with a minimum of friction. What is required is a deep transformation of structures that ensures the largest and most effective force contribution that can be made on the basis of the available limited resources.

\section{The level of political-military co-operation}

The focused development and use of the armed forces of a state depends on an effective and trustful dialogue between the elected state politicians and the formally appointed senior officers. In a reformed situation, the following relationship has been established.

The directly responsible politician, normally the defense minister, will communicate the political priorities and limitations guiding defense policy openly and effectively to the senior officer corps. He understands that he is totally dependent on advice from his senior officers represented by their senior representative, the chief of defense, and that he relies on them for the effective implementation of decisions by the armed forces. The chief of defense understands and accepts that his role is limited to a subordinate one of advice and implementation. He will, to be efficient, have a deep professional understanding of the capabilities and limitations of the existing armed forces and the potential of any planned or possible developments. This understanding can only be developed through a combination of professional and personal maturity gained during a protracted and varied service. It needs to be created and maintained by actively seeking to be updated about the condition of the forces and by having developed a positive empathy with both the role and situation of the politicians he is serving and the situation in the different armed services under his command. The chief and his associates must accept deep in their hearts that they have to serve the elected politicians in the government loyally, no matter what they think of them or their policies. In a mature democracy, military leaders have no formal or informal direct responsibilities to the nation.

This reformed situation is not easy to generate. A legacy of the past was that the new post-1989 politicians deeply mistrusted the leading military figures, and tended to seek the advice they wanted to hear by bypassing the formal leaders, or by getting it from foreign advisors. In some cases the advice, if any, from the existing professional military was so far removed from the requirements, and so irrelevant, that no advice was sought from them thereafter. On the other hand, the reason for not seeking advice could, in some instances, be that the politician simply did not think that he needed it.

The professional military for their part were generally unsuited to play their role in this new relationship. Very few accepted that the government, made up of 


\section{THE QUARTERLY JOURNAL}

"amateurs" who served a party rather than the nation, could have any real authority over national security matters. Subordination to the president might be accepted, but not to a "politician" from the parliament. Having developed professionally in a dictatorship, where the armed forces had to worry only about the preparation for total war, senior officers found it close to impossible to understand more limited roles for the armed forces and accept that a dialogue with the "amateurs" was necessary. The smaller the state, the more difficult it was for ex-Soviet officers to adjust. Nearly all the senior army and many air force officers simply lacked the professional depth to create other types of forces than those they had been programmed to operate. They were also handicapped by a dictatorial and centralized management style that hindered effective interaction with talented subordinates.

A precondition for the easy creation of a dialogue based on trust is, however, that the politicians chosen as defense ministers are eager to develop the necessary co-operation and that they understand the need for good interaction. Another obvious requirement is that they, and the civil servants that assist them, must be trustworthy, honest, decent, capable, and mature persons. It would be very difficult for a senior, grizzled professional, who, by definition, is willing to lay down his life for the nation, to respect a corrupt, self-serving character as his boss. Nor does it help foster co-operation if he routinely transmits his decisions indirectly, via unjustifiably self-confident, newly employed, young civil servants.

In the Baltic states, the situation was often even more complex. As mentioned above, persons from the volunteer and paramilitary forces without any regular officer education gained a key role in the development of the armed forces. Thus there were two groups of senior military personnel, none of them with a background that prepared them very well for their part in the political-military dialogue in a small democratic state. In these three states the transition has depended on the leading professional positions being filled by officers who received most of their service experience and education during the post-1991 period. A full generational change must take place within the next few years to ensure the proper use of state resources and an effective integration into NATO.

In all CEE countries, successful transition requires an accelerated generational change in the leadership from the rank of colonel upwards combined with a drastic slimming of the bloated number of officers of high rank. A well organized and supported retirement scheme is thus a precondition for reform.

\section{The unit level}

The problems of the unreconstructed armed force structure are clearly visible at the bottom of the structure, at the unit level. The key purpose of a peacetime military structure is to develop and maintain high-quality units (battalions, ships, air force squadrons) at various states of readiness. The first step in fulfilling that purpose is to ensure high-quality, professionally and personally mature unit leadership. The structure must ensure that the very best mid-career officers are ro- 
tated out from the central staff and training elements to command units. This is necessary to ensure that the units have the best leadership possible and to create a professional foundation for later work in senior staff, military education, and command positions. The personnel management system should make certain that the very best compete hard to get unit command, knowing that without a successful period as commander, their career will be limited to specialist fields and they will not reach high command posts. The system, however, should also ensure that rotation between posts in different parts of the country is supported economically and by common-sense regulations so that the families of the best officers feel reasonably well supported.

The unit should have a very high and demanding activity level in order to ensure that the officer develops and is tested as unit commander. The commander should have considerable freedom of action, even if his performance in all fields is evaluated continuously. In good Western armies, a senior officer with recent, very successful unit command experience — in the army, normally a brigade commander-carries out a key role in the evaluation. As the future leadership is serving as unit commanders, the central staffs keep in close contact with the units to ensure that their administration is supporting unit effectiveness.

This situation is very different from the pre-reform situation in the Central and Eastern European armed forces. The units were commanded by very young officers in the army, normally captains. They had little or no freedom of action. The center inspected their work, but they had absolutely no influence on developments and decisions at that center. Their life and that of their officers mirrored the provincial garrison life of Chekhov's plays, just without the more charming fin-de-siécle elements. If they were lucky or well connected they escaped early to a position in the central administration and to higher military education. Most stayed in the center, quickly becoming bureaucrats or teachers with only a faint, very theoretical link to the reality of life in the units, abhorring the very idea of ever returning to these units.

Efforts at creating a well-functioning rotation system in the CEE armed forces are very often undermined by the following four factors:

- The officers see no reas on why they and their families should suffer when the politicians, civil servants, and senior officers above and around them act with little or no public or professional spirit.

- The politicians and senior commanders do not want to let their best and most intelligent military assistants depart for the provinces.

- There is little or no understanding of the fact that practice is more important than theory in creating military effectiveness.

- In a world where the Potemkin facade is much more important than the reality, the units do not count. 


\section{The Basic Combined Arms Formation level}

Western armies have found that the existence of the basic combined arms formation headquarters level, normally the brigade, is necessary for the development of an officer corps in the units with a practical, professional understanding of combined armed tactics. The unit, or the battalion, will, in its training program, have to concentrate on the training of the sub-units, the companies, specializing in developing effective handling of the "tools" organic to the unit. Therefore it is nearly impossible for the unit itself to create and conduct realistic training in order to develop the ability of the reinforced unit staff to operate effectively together with other combat, combat support, and combat service support units or elements. On the other hand, it is also close to impossible for a central joint planning and administrative staff to develop and conduct a realistic field-training program single-handedly, because the focus and main activities of such a staff makes it unsuitable for such training. A special central service training staff-an army Training Command-may be used, but it is likely to lack that organic communication framework and relevant professional mix of expertise and direct unit focus that is inherent to tactical-level formation headquarters.

Most CEE armed forces had tactical formation HQs; they only needed to be reformed in their focus and activities. However, that was not the case with the Baltic states. This was due to the fact that they started force development from scratch and did not consider combined armed tactics relevant. The maximum the newly created forces would be able to do at the outset against the overwhelming Russian threat was a marking of national sovereignty at the border, followed by guerrilla actions with light infantry and engineers in the forests. But the new NATO mission framework for operations inside and outside the region has created new professional requirements. The training of the unit level officers in the Baltic states has so far suffered from the lack of formation-level training activities. The Lithuanian "Iron Wolf" Brigade Staff is only now developing into a tactical formation HQ. The Latvian Motorized Brigade HQ existed at first only in name, and was abolished thereafter. The Estonian General Staff did not realize the need for mid-level tactical HQs until recently, and then only under political pressure.

All CEE armed forces should in fact understand that a tactical formation staff should be seen and built as a small team of flexible professional generalists that operates with the support of a few watch-keepers, communicators, as well as security and transport personnel, instead of the current model under which such a headquarters is merely perceived as a bureaucracy of specialists that support the commander when ordered to do so. The effectiveness of a tactical HQ does not depend on the size of the peacetime staff, but rather on the quality and relevant practical professional experience — and ability to work as a team-of its core personnel. There is an unfortunate tendency to create a staff by the immediate filling of office space with officers (defined as persons in uniform carrying officer's 
rank), rather that the gradual building-up of staff as experience is gained and real workload increases.

A fully-manned basic tactical formation HQ is organized as a pool of small functional teams, each made up of a couple of planners and a few assistants. The teams either conduct current operations or they reconnoiter and plan future operations, the immediately following operation, or possible contingencies. In order to reduce vulnerability and plan simultaneously conducting current operations, the fully-manned staff should be large enough to establish two to three command posts manned by a combination of these small functional teams. The staffing level should also ensure that there are enough assistant watch keepers to control intensive operations for 24 hours a day for an extended period without rest. However, keeping such a large fully-manned tactical staff during normal peacetime training conditions makes certain that the staff "rot" due to lack of meaningful work. This is what happened in the past.

In the West, only formations like the U.S. immediate reaction formations that combine an intensive exercise level (both by higher headquarters of the formation and the formation conducting training with its subordinate units) with constant contingency planning for possible worldwide deployments may avoid bureaucratic rot of the staff. In all other cases, a fully wartime manned staff will quickly deteriorate though formalism and laziness. Therefore the only solution is to limit the daily staff level to those who can be properly occupied at the defined activity and readiness level. In a British mechanized or armored brigade staff, the peacetime staffing is limited to nine officers and 27 of other ranks. The staff will, however, need to exercise regularly with the augmentation of watch keepers and liaison officers to properly practice operational procedures. These augmentation staff officers may come from the reserve cadre or from the regular training structure cadre. In the British case, the augmentation consists of fourteen officers (one senior liaison officer and thirteen watch keepers) plus six officers attached from the combat support units.

\section{The Central Staff level}

Another side of the problem was the situation in the central, or General, staffs. The Soviet/Warsaw Treaty Organization experience led to the creation and maintenance of structures that saw their role as both narrow and total. Under this model, the staff was to control the preparation of the forces (land forces and supporting air force elements) for war, a total war that justified high-priority access to all resources of society. The role of the politicians was to make sure that the resources would be made available, as the only role of the armed forces was to defend the future existence of the nation. Within that mission framework, the only militarypolitical dialogue necessary was the military answering questions from the political side about how the defense requirements could be met in the best possible way. The staffs tried to cover all aspects of defense-related planning and admin- 


\section{THE QUARTERLY JOURNAL}

istration, but the focus was on the creation of army units in a manner unrelated to the available resources and the theoretical concepts for their use in war. There was very little interest in the more mundane administrative work of developing effective use of finances, accounting, materiel, and personnel, and the development of proper supporting logistic structures. The other services-air force and navywere formally under the central staff, but in reality left to develop as separate entities.

At the same time, the Soviet bureaucratic tradition led to these staffs being bloated in personnel, unfocused, totally centralized, decision- and responsibilityaverse, with activities unrelated to the reality in the units, and interested in planning and concepts rather than in learning through implementation. Relations within the staff and with other authorities and staffs at the state center were often hampered by a lack of clear lines of responsibility, detracting from the creation and maintenance of a quality product. Seen from the outside, and from the units, the central staff was a very large group of inert, ineffective, self-serving bureaucrats, selected on the basis of rather empty higher education credentials rather than proven professional, analytical, and administrative ability.

In order to effectively lead and implement reforms, these central staffs have had to be transformed in every sense. The end-state of the reconstruction should be a flat hierarchical network of co-operating small teams, each team with a welldefined responsibility and delegated authority. These should be joint service in nature, and the main function should be planning of development, general administration, and control of implementation at the highest policy level in direct support of the chief of defense and in close interaction with the minister of defense. Collocation with the MoD will ease co-operation and make continued duplication of effort less likely. At the same time, collocation will underline the requirement for strict discipline in the maintenance of good staff procedures and clear responsibilities on both sides. The central staffs should be drastically reduced in size, emphasizing quality of personnel rather than number, in order to become more focused and effective.

Control of operational planning and control of operations is to be performed by a commander with a small joint service operations staff. To minimize duplication of effort and reduce the size (and increase the effectiveness) of the central staff, the operations staff may only be a partly separate organization, in a location close to the central staff, supporting the joint planning and administrative staff with staff work in the purely operational field. Both these two joint central staffs will keep a close link with conditions in the units by regular rotation of key personnel and by a new organizational ethos emphasizing subservience to the two levels of clients: the political masters and the units. Such much smaller staff elements will be much more able to deliver high quality, realistic "products" on time.

At present, very few CEE armed forces have come close to having such small 
and focused central staff structures. It seems to be very difficult to get rid of the ideas that bigger is better and that keeping all responsibilities and functions directly under the control of one person and in one staff is the right solution. The users - the politicians and units-are suffering as a result.

One problem has been uncertainty about the roles of the service staffs. The central Staff was also the army staff, as that staff was mainly seen as an operational staff concentrating on using the main armed service, the army. If an air force with a fighting capability existed, it might be partly integrated and given a reasonable priority. Otherwise, the air force as well as the navy would be seen as fairly irrelevant to the defense effort, and therefore left as orphans to develop on their own, fighting their own, successful or unsuccessful, political battles for resources. With a combination of a joint central staff and a joint operational staff, the remaining critical task of the individual services (commander/inspector with staff) is to maintain and develop the training and readiness of the units as well as being a center of service-related professional expertise that can be used as a platform for the development of tactical structure and procedures. In order not to have overlap with the work of the joint staff structure planning elements, the service staffs should be closely collocated with that central staff. Such a development of small focused service staffs would be hindered by the creation of an independent joint Training Command.

If a joint Training Command is made responsible to the chief of defense and operational commander for the delivery of unit quality and readiness, this then takes away that core responsibility from the senior officer of each service, and removes accountability for quality from expertise. It is not safe to sail in a ship or fly in an aircraft where the training directives and standards do not reflect a combination of a high level of service professionalism and a clear and acute feeling of responsibility by the issuing authority. The development of joint Training Commands is a result of an inappropriate imitation of a successful U. S. service institution: the U.S. Army TRADOC.

A special problem in the central staff structures has been the establishment of a proper logistic system. When the logistic system has been both reformed and developed, it will ensure effective, timely, and sufficient support to the units in both peacetime garrisons and on international operations or after mobilization. The service will be provided by a transparent system that ensures honesty and minimizes waste through constant outside scrutiny. This is a long way from the chaotic and sometimes corrupt logistic systems that were left as part of the Soviet legacy of wasteful managerial methods and self-serving attitudes among officials.

\section{Manning the armed forces}

In Soviet-style armed forces, manpower was recruited by conscription of, in principle, all young men for a long period of service in the military. In those forces the individual was deliberately suppressed through a combination of collective pres- 


\section{THE QUARTERLY JOURNAL}

sure and punishment as well as a brutal formal discipline. The service of enlisted soldiers had the character of time-limited slavery. Sons of the privileged classes would normally stay separate from the serving majority, only participating in "reserve officer" training and camps, linked to their diploma studies in universities or other institutions of higher education.

A gradual development away from that system started early in many CEE countries. However, even if the treatment of the soldiers improved in many states, armed forces staffing was still dominated by the group of draftees from the less privileged part of the male population. The relatively low cost of the system supported its continuation, even if the changing spectrum of missions and readiness requirements underlined the need for change. In an effective, reformed armed force, able to conduct a variety of operations rather than the large-scale war that the mass conscription based forces prepared for, the staffing strategy must be very different. This does not necessarily mean that conscription should be completely abandoned in favor of a contract soldier system. However, a reformed structure must have a very strong presence of regular NCOs and technical specialists, and elite units on high deployment readiness must be fully manned by regulars.

The possibilities for recruiting a sufficient number of high quality young men and women to man and sustain the necessary force structure at home and on deployment may rule out a straightforward solution. A high youth employment rate makes a situation with serious recruiting problems likely. A reformed manning structure could - as in some Nordic states - consist of a mixture of a strong cadre of regular long contract NCOs, regular contract soldiers on high readiness, and, in technically very demanding jobs, some of these volunteering for contract service during their training as conscripts. Units may have a strong component of regular reserve personnel with a high readiness force contract; these personnel normally will have full conscript training plus the experience from six months or more service on international operations. Only the parts of the armed forces needed for the purely territorial self-defense mission will have a strong component of conscript reserve personnel. In order to make such a "professionals via conscript training" system workable, the conscript training should be thoroughly reformed so that regular service and a high readiness force contract is seen as an attractive option, creating a high number of qualified volunteers.

One benefit of a mixed system is the ability to sustain long deployments of a relatively large number of personnel. In such a system this can be done without having to increase the size of the standing force or wearing the existing force down by too frequent absence from their families. This burden on the families of regular military personnel has been a major issue in several European armies during the last decade.

However, the key element is a high percentage of good regulars who can absorb and train the gradual influx to the required high level. Therefore it is important that the net for recruiting quality regulars be cast as wide as possible, 
including deliberate attempts to attract national minorities, which in Latvia and Estonia means Russian-speaking non-citizens.

\section{The officer education system}

The typical officer education institution in the Soviet tradition had two types of faculty members, whether it was a military academy or a general staff academy. The leading group consisted of aging professors of military science, colonels or generals who had been conducting postgraduate and doctoral studies in this or similarly organized institutions and who had served there for fifteen to twenty years. They were supplemented by a group of civilian academics, totally dominated by natural scientists. The study program of the full officer education system had many levels: company-battalion, regiment, division, army, front, staff, general staff. The purpose of each was to ensure the mastering of the scientifically correct command or staff procedures of that level. The education, even the highest, focused on purely military matters, related to preparing for and winning a major war and then handing that successful result back to the politicians. The purpose of the education was not so much learning to think and work professionally in a general sense, but of ensuring that the officer would be well drilled and indoctrinated to fit well into the next higher position. The postgraduate study programs had either a natural science or a military science focus, the latter preparing the future professors that could sustain the institutions.

This system is totally different from the military education system of Western type armed forces. Here, the faculty is also usually a mix of officers and academics. However, the officers must be persons with recent practical experience in the units or staffs who can pass on updated knowledge and skills. They should come from the top part of their class, be relatively close to the cadets or students in terms of age, able to act effectively as professional role models, and, after their two to four year period as teachers, if successful, be rotated back into the forces to an enhanced career. Career people should likewise dominate the group of civilian academic faculty members, some university academics on a part-time contract with the school, others on time-limited contracts with the institutions. Some may have natural science backgrounds, but academics with a background in political or social sciences and humanities should form the largest part of the group. The education system will tend to have three or four levels: the basic officer education, a short junior staff course, and a command and staff course. The first level will prepare the young officer generally and for their first practical assignment. The second will supplement the basic education and will be given to all regular officers. The third level will only be relevant for the top ten-thirty percent. It will build on the professional understanding generated by around ten years of practical service and will encourage and assist the officers in developing themselves during the rest of their career. The course will endeavor to deepen the understanding and acceptance of the way that the armed forces of a democracy must 


\section{THE QUARTERLY JOURNAL}

interact with the civilian structures and be subordinated to political control. Any fourth-level education will normally concentrate on that specific issue as it is seen at the time of the course to prepare the course members for high command. In their attitude to the general and academic civilian education of the officers, the society and the elected politicians must come to understand the rather limited relevance of civilian academic credentials to the quality and loyalty of the officer corps. A good democratically-oriented officer corps is developed by its constant interaction-during both education and service-with the civilian society that it serves. The very close links and constant interaction between the military and the civilian and political sides make the field of an exclusive "military science"other than professional understanding - meaningless. The two structures, their purpose, and their products could not be more different, and the Soviet-type indoctrination structures must be thoroughly changed and reformed to help other developments.

\section{In relation to general staff officers}

The system for developing, educating and training officers reflects basic differences in how an ideal general staff officer is seen and in what profile a representative of the intellectual elite of the service has. In a thinking armed force, the ideal is an officer with a thorough practical service background. That background interacts with theoretical schooling and a developed character to create a holistic thinking generalist with a deep sense of responsibility towards the defense mission. He/she has a well-developed tendency and ability to think and analyze "outside the box" and to present findings regardless of their popularity while at the same time remaining a loyal and effective implementer of any decision made by the commander. He/she will actively seek development and results rather than privilege, and will interact closely with the units as he also sees himself as their servant. The personality profile and education is fundamentally different from that of a Soviet-type general staff officer, who was seen as a long-serving specialist, awaiting orders to act, even if the results were clearly "inside the box." $\mathrm{He} / \mathrm{she}$ was not supposed to think or act without authority, and was basically a "staff technician."

\section{The personnel management system}

In a normal good quality armed force, there is a clear and generally accepted connection between rank and position on one side and ability on the other. The foundation of the personnel management system is based on a clear definition of the education, practical experience, age, and personality requirement of each cadre and specialist position in the peacetime structure and fully mobilized force. Recruiting and formal training takes place and individuals are rotated between different positions and practical experiences to fulfill the requirements. Independent selection boards that must ensure against favoritism administer a personnel 
evaluation system that endeavors to give an objective picture of the development of each member of the cadre or specialist. The pay and social system must make certain that rotation between jobs-necessary to create practical professionalism in the cadre - can take place without undermining the welfare and cohesion of the soldiers' families. The retirement system ensures that the armed forces avoid carrying a burden of persons who do not fit into current and foreseen requirements for cadre and specialists.

Such a system may have existed in the CEE armed forces a generation or two ago, but the general development of society has probably been the reason why that focus was lost. Therefore a proper system has to be developed from scratch, including a focused and Western-type understanding of the education and service background as well as personality requirement of each position. The evaluation and selection system must be reformed completely to remove favoritism and clientism. Selection must be based on demonstrated high quality. Rotation must be enforced and supported, as must early retirement. The system must ensure the right combination of relative youth and practical professional experience throughout the structure. There must be a balance between the number of officers graduated from the basic officer education and the positions, mainly platoon leader and other subaltern officer positions where they can get practical experience. Without a system that bases promotion and employment on proven quality, the officer corps will remain a battlefield, dominated by loyalty and favoritism linked to individuals and political maneuvering among cliques.

\section{Conclusion}

The transition to effective, "best-practice" Western-type armed forces will achieve the following results:

- Military-political co-operation with a military leadership that combines a deep and updated professional foundation with an acceptance and understanding of its role in relation to the political leadership of their country;

- A generational change in the now very reduced group of senior officers;

- The existence of a truly professional officer corps managed by a personnel management system that aims at absolute fairness, gives high priority to service in units, and that demands and supports rotation of key officer cadre personnel every two to three years;

- A firmly rooted understanding in the central staff structures that their main task is to develop and maintain effective units, within the important context of the tactical formation level in the army;

- Drastically slimmed and task-oriented central staff structures; 
- The existence of service chiefs/inspectors who have a clear responsibility to the joint operational commander and via him to the chief of defense for unit quality;

- A reformed staffing system, adjusted to the size and mission of the armed forces;

- A reformed and pragmatic officer education structure;

- A dynamic general staff officer corps with sizable group of members with the ability and moral courage to think and debate "outside the box," with the understanding of the political and professional leadership which is crucial in a democracy.

\section{Finally: A look to the West}

Some elements of the development challenges discussed above are also relevant for many continental West European states. During the last half-century, their armed forces have developed strictly within the tight framework of the East-West confrontation. It dominated all structures, all thinking, all education and training.

As the task of the armed forces became clear during the 1950s, the actual organization of defense could be, and was, delegated by the politicians to the professional military led by the defense chiefs. There was no need for constant and close interaction between the defense minister and the chief of defense except in matters of the future budget, relations to the alliance partners (for the NATO members), length of conscript service, and the role of the national defense industries. Thus there was no need to collocate and integrate the ministry and the defense staff, and the minister of defense was normally considered as one of the junior cabinet posts. The need for close interaction between the political leaders and defense agencies in crisis and war was, however, realized as a result of the Cuban Missile Crisis in 1962. It was exercised in special inter-ministry and department contact groups, but the daily interaction was weak.

The armed forces were specialized for the foreseen missions of "the big war," focusing on territorial self-defense and reinforcement of the territorial defense of the front-line states. The forces depended on the deep mobilization of civilian resources, including reserve cadres and other manpower, and the effectiveness of the expanded forces depended on the thorough, common tactical indoctrination of both regular and reserve cadres. The mission, the actual terrain where the defense would be conducted, and the available forces were all known in advance. Even the enemy was thought to be well known, including his standard tactical and operational drill. As the Cold War became a routine in the early 1970s, preparations to fight for freedom and survival became less urgent. The mission of the armed forces became first and foremost to contribute to the deterrence of an attack. In many West European armed forces, this led to the stagnation of profes- 
sional studies and debate, and then of force structure and doctrinal development. The regular cadre obtained rights and service conditions that mirrored those of the civilian environment rather than the requirements of their chosen profession. The requirement for independent professional thinking was diminished in both the professional education and in the service of regular officers. U.N.-mission service was the only source of "out-of-the box" operational experience available. However, as these operations often took place in low-intensity, stable confrontations, carried little prestige, and were guided by well-established Standard Operating Procedures (SOP), service here did not inspire professional development.

This has led to a situation where many West European military structures face challenges, such as:

- Relations between the political and professional leadership must be adapted to mirror the requirements of conducting and managing current and (militarily as well as politically) risky operations. A combination of the amalgamation of the Ministry and the Defense Staff and the creation of a national joint operations HQ has demonstrated its potential for the co-ordination of the political and military leadership while at the same time allowing for the integration of all relevant joint expertise in a professional environment.

- The operational forces must be organized as flexible "tool boxes," where the elements are equipped and well exercised in co-operation between themselves and with forces from other states.

- Even the mission of defending national territory against threats is seen as a complex task, calling for flexibility in both direct response and in force expansion as well as the ability to co-operate effectively with other national and other states' agencies.

- The education of the regular cadre needs to develop the will and ability to adapt the use of the available personnel and equipment to the actual task and situation, if necessary without guidance from above. The requirement is as relevant for a platoon leader, at his level, commanding a detachment in a Crisis Response Operation, as it is for the designated task force commander interacting with the political leadership in the preparation of a new mission. Education and training must develop the understanding of the strengths and weaknesses of the different military tools under various conditions rather than supply a ready-made set of doctrinally correct responses.

The irony here, of course, is that these are similar in some areas to those requiring reform in the CEE states. Complacency in these matters is something none of us can afford. 